UDK: 336.748.5(4)

DOI: $10.1515 / j c b t p-2017-0018$

\title{
Eurozone Debt Monetization and Helicopter Money Drops: How Viable can this be?
}

Email:

knikolaos@uth.gr

\begin{abstract}
After the outburst of the recent financial crisis, the subsequent unconventional monetary acting that seemed to be a veritable revolution tends to become a norm. This paper makes an effort to employ the modern monetary theory framework to address the nowadays recession in the Eurozone through the prism of debt perpetuation and the more drastic helicopter money drops. Dynamics of debt monetization and issues of its sustainability are examined in connection to its free liquidity injections capacity. The aim of this paper is to try to cast some light on the potential of overt money financing in the Eurozone (EZ) and its consequences on the ECB's credibility and the maintenance of its efficacy.
\end{abstract}

JEL classification: E52, E58

Keywords: Unconventional monetary policy, Helicopter money, Debt monetization, Eurozone

\section{Introduction}

Monetary policy easing in the major developed countries such as the US, the UK, Japan, as well as in the Eurozone, has been at the center of academic debate since the onset of the 2008 global financial crisis. Theoretical economists but market practitioners as well have been willing to better discern the impact of liquidity injections on the real economy and financial markets. This has led to a voluminous relevant academic literature and has evoked conflicts between supporters of easing policies and proponents of monetary stability. 
By taking into consideration expectations about further monetary easing by the $\mathrm{ECB}$, and having in mind that a new QE round or a helicopter money drop could be about to emerge, much questioning has risen about suitability of further easing. This paper tries to provide some insights into whether helicopter money drops -that is providing irredeemable fiat money to the economy-could provide a suitable measure for keeping the Eurozone's financial engine warmed up. This is examined by being counterbalanced with a potential loss of central bank credibility and a decline in further easing efficacy that such a new modern money theory implies for radical monetary actions like helicopter monetary drops, the analysis being based on Minsky and Kaufman (2008). While the intention of this paper is not to suggest that this is the best approach to be adopted when looking into the nowadays situation in monetary economics, we believe that it could constitute the basis for a new though historically-originated way of thinking. This could be helpful for economists to formulate an opinion and tender advice about whether the view at issue here could prove useful or not.

One of the main questions that have to be answered regarding new unconventional policies is what is required to counterbalance their costs and benefits regardless of the extent to which they affect the viability of the Eurozone and could irredeemably damage the European monetary authorities' credibility. In other words, could the ECB preserve the rumour of being independent and credible after successive rounds of QE and, eventually, helicopter money drops? In order to give a firm theoretically-based reply, one should clearly make up their mind about what modern money theory implies concerning debt monetization and how high would be the risk of financial collapse if most economic agents refused to pay their debts on time. By taking into consideration the bank-centric character of the ECB that attributes to banking institutions' role of the primary moving force for economic development, one could justifiably ask oneself if banks -as the biggest debtors in the world- could always avoid paying their debt with no consequences whatsoever. By bearing in mind how heavily indebted are large banking institutions nowadays, one should always wonder how endangering this excessive borrowing could prove. By accumulating large amounts of debt, banks are able to make profits but at the same time increase the risk of confronting a bankruptcy, as the more they keep on capitalizing on other people's debt, the more difficult it becomes for them to liquidate their debts. Modern money theory indicates that money's existence would be impossible without the simultaneous existence of a debt that will never be discharged (Sgambati, 2016). This is to a large extent due to monetary scarcity of precious metals to be connected with money printing and thereby liquidity creation. It could therefore be characterized by as much more than a random common thinking that bank intermediation is nothing more than creating money out of nothing, having its origins in the chartalism theory sup- 
porting that using tokens economizes in real resources and is especially useful during crises and generally in periods of liquidity drainage. Abiding by the redistributional character of financial intermediation as its primary objective, it could easily be derived that bank profit maximization has real economy profit-making origins as banks are only an intermediate in the credit infusion process to economic units.

The remainder of this paper is structured as follows: Section 2 provides a theoretical background for money creating and liquidity dynamics. In Section 3 the positive effects of debt monetization and the benefits of helicopter money drops are examined, while Section 4 furnishes the counterarguments based on credibility risks and discusses the impact on EZ perspectives. Section 5 provides the conclusion.

\section{Theoretical background of money creating and liquidity}

If one employs the fractional reserve mechanism in an effort to understand how the time structure of a bank's balance sheet works, they will inevitably observe great asymmetries between time horizons in the liabilities and the assets sides, which is much more long-term oriented. It could thus be deduced that due to this apparent maturity mismatch, a banking institution abiding by the fractional reserve mechanism is constantly inherently bankrupt, with the burden of a nonnegligible debt. Problems like this though are easily solved due to the interbank market for reserves and a clearing facility, which should be working smoothly in any condition.

This character of interdependence in the banking system is highly likely to turn the other way round in times of financial crises, where the banking system's credibility becomes lower, and the need of borrowing in the interbank market becomes greater, whereas at the same time, other banks become risk-averse and reduce fund supply among banks. This forces banking institutions to be susceptible to fire-sales in order to satisfy increased fund demand by their depositors and consequently leads to a deflationary bulge. How burdensome could this default spiral become? Could irredeemable helicopter money become a remedy to this apparent dead-end? The sustainability of debt seems to be in the core of this answer. How powerful could fiduciary money that does nothing more than enhance debt accumulation prove to be? Is debt sustainability able to equilibrate supply and demand dynamics forever? For how much longer would the unconventional nature of fiat money survive and pertain in more unconventional forms without 
the risk of a bubble-economy bursting? Is "too-big-to-fail" just a phenomenon of an impermanent and fading-out character?

One could hardly disagree that liquidity is tightly connected to new money making. Nevertheless, the two meanings are not exactly the same, in contrast to what many people would think at first blush. The ability to use money for trades, as a market instrument, is what renders money useful. Thereby the liquid or not condition of money could be claimed to be more important than money itself. This is that constitutes the main difference between QE-injected money and helicopter money. In the first case, money is provided by asset purchases but does not affect households' willingness to consume or firms' eagerness to invest to the extent that monetary and fiscal authorities would probably desire, owing to taking into consideration the ephemeral character of freshly provided liquidity. On the other hand, irredeemability of helicopter-dropped money that will never have to be paid back is probably much more influential to the public's expectations. This would affect their actions in favour of the outcome intended in the first place (Shiller, 2015). One could with no hesitation characterize helicopter money as the most unconventional of policies, at least according to our knowledge until now. The main drawbacks of unconventional policies in general are: the diminishing efficacy of new rounds of non-conventional measures, the increasing difficulty of swapping up the extra liquidity injected when return to normality becomes essential, and the weakening of monetary authorities' credibility and trustworthiness as new unconventional policy rounds arise. The increasing uncertainty due to the financial crisis, the non-linear costs for the economy due to domino effects and the high level of leverage and inter-connectedness in the financial sector, as well as the irrational exuberance and moral hazard that ample liquidity provisions can evoke, make this calculation of loss a Herculean task. Modern money theory openly supports that money creation is entirely a financial phenomenon, thereby attributable to the banking sector.

Although debt monetization used to be a very old practice exercised by kings and considered as immoral regarding the distribution of tax burden, indebtedness has intertemporally been accepted as a means of perpetuating and maintaining purchasing power and providing fresh income that keeps the engine of the real economy still working. The main function of the central bank has always been to remain a benchmark of credibility, the one that furnishes the legal tender to money circulating in the economy and is used to finance public expenses. This irreplaceable concept is that credibility forms a sine qua non for indebtedness to be preserved by the mutual will of both counterparties in order for the credit character of money to be efficient through its high elasticity dynamics. One could easily wonder about how ethical is new ample liquidity providing that lessens the 
real value of already existing money. This could probably be explained by considering bank functioning not as a procedure where debt is exchanged for credit, but preferably as one where debt is exchanged for debt. That is the debtor and the creditor should no longer form a creditor-debtor relationship, but a debtordebtor one, shaping a mutual indebtedness where a debt bearing interest could be exchanged with another debt redeemable on demand (Kim, 2011). This would be in full accordance with the notion that every economic agent owes money but never owns them, he just owns a debt due to his capacity to convince the counterparty that he is trustworthy enough to owe and transfer his payment obligations into future periods. In other words, money is so dynamic that it cannot be framed and it emancipates people from time and fund constrains that hold back economic growth due to maturity mismatching. Unconventional monetary policies tend to assist economic units, primarily through the developed banking system in the Eurozone, to better allocate their assets in time and capitalize other people's debts in order to be liquid in their formation. The question posed is for how long this interaction could keep up without one of the debtor-debtor counterparties deciding to ask the other to repay his debt by not issuing further debt. In other words, how many rounds of economic interacting will have to go by until people's expectations unavoidably become pessimistic? Modern money theory supports that debt renewal could be perpetuated forever and it is the sentiment of safety that the credibility of counterparties exerts that allows for this non-stopping character. New unconventional monetary policy rounds could easily boost economic agents' confidence that yields will remain low and investment will not become more costly because of new money printed and provided by the ECB. As Mehrling (2000) argues, there is always a hierarchy in monetary systems, with debts of higher quality circulating as money to lower quality debts. The interest paid for the renewal of debt represents the uncertainty emanating from transferring debt into the future. Debt monetization by the ECB via helicopter money drops could fairly well surpass the institutional limits of cash, enhance confidence, and diminish the importance of collateral and hard currency in financial trades based on debt.

\section{Positive effects of debt monetization and helicopter money}

A voluminous extent of concern is therefore raised by the self-perpetuating character that unconventional policymaking has shown to present, if the necessity of new rounds of QE in US, UK, Japan, and the Eurozone is considered. Simply put, flight from money scarcity and the increasing elasticity of money supply makes the marginal impact of extra liquidity decreasing. Fiat money with continuously larger deviations between its intrinsic and its nominal value, make money sub- 
stitutes more and more weak, thereby lessening their credibility and fuelling new inflationary bubbles, raising fears that helicopter-dropped money will be so light and thereby in need to become too numerous to counterbalance the crisis. Moreover, moral hazard incentives leading to excess risk-taking make the efficiency of debt monetization dubious, thereby rendering the last arrow in the quiver of the ECB less sharp than desired. The possibility of a new liquidity crisis after helicopter drops have been implemented would leave monetary authorities with an economy stuck at the Zero Lower Bound (ZLB) and in need of much new creativity to get over such a situation.

One of the most promising characteristics of helicopter money is that it increases economic units' net wealth, thereby provoking a pure wealth effect of monetary policy on consumption demand (Buiter, 2005). In other words, the present discounted value of the final stock of money is a component of the private wealth after having taken the government and the household's budget constraints into consideration. Thus, irredeemable fiat money is believed to be an efficient means of affecting real consideration by managing to exercise an impact on the present value of future endowments. According to Buiter (2005), monetizing the debt has the advantage of overcoming debt neutrality and not be subject to the Ricardian Equivalence theorem that supports government non-monetary debt not being net wealth. Moreover, Buiter and Sibert (2007) prove that irredeemability of debt leads to exclusion of deflationary bubbles, even when both money and bonds are issued. Furthermore, according to Friedman's optimum quantity of money (OQM) equilibrium, all liquidity trap equilibria as well as deflation equilibria are ruled out due to the weak real balance effect that the monetized non-redeemable character of debt brings about.

A prominent feature of high importance of monetary policy in the authorities' effort to maintain a low possibility of liquidity drainage due to sudden deposit withdrawal increases is managing to preserve optimistic sentiments among investors. Differently said, a salient matter is the ability of perpetuating public's expectations that the long-run money stock increases will not be reversed and that liquidity traps could be avoided. Shiller (2015) argues that investor's positive sentiment is able to keep on leveraging economic activity and promoting inflation, thereby maintaining the financial system alive and vivid. It could be difficult for someone not to make out that in a bank-centric financial construction such as the Eurozone, the importance of economic concepts such as optimistic expectations gets particularly large, especially in times when breakthrough discretionary actions are required. One could logically wonder if debt monetization and the perpetual character of debt renewal and fresh liquidity pumped could be applicable in real economy. Though not having to take off one's mind from that 
that a non-negligible amount of conditions have to be valid, it could be claimed that currency is highly negotiable and very elastic regarding its maximum extent of nominal to intrinsic value difference, as well as its money multiplying dynamics. In simpler terms, currency is a bearer bond that can be freely negotiated. This happens due to broad money being made up of two forms of IOUs, that is: i) bank deposits being headed from commercial banks to households and companies, and ii) currency, primarily meaning IOUs from the central bank, though the latter is much less voluminous than the former (McLeay et al., 2014). The vast network of banking intermediaries in the euro area enhances new money creation not by producing large streams of new banknotes, but simply by crediting economic agents' bank accounts with bank deposits that have the same value as the assets traded. The commercial banks' loading their balance sheets with new loans and new deposits lubricates the financial system's machine and spurs economic growth if these new balance sheet components are not required to be redeemed. Bank deposits are nothing more than a liability of a bank, not an asset that could be given to a borrower. One could easily claim that deposit withdrawals constitute money destruction. Banks buy and sell government bonds, but also do monetary authorities, thereby creating and destroying amounts of money. Unconventional monetary practices include buying long-term bonds, thereby injecting money into the economic system through QE balance sheet enlargement operations. It should not be neglected though that sweeping up the extra liquidity by re-selling bonds could lead to a new crisis if leaving $\mathrm{QE}$ is not made gradually. This is because QE-exit-provoked liquidity shrinkage by short-term money returned for long-term debt could be considered as money destruction. Even with money injections during non-conventional practicing, it could not be assured that money balances will be higher, as debt repaying could absorb a large portion or even the entire newly-injected liquidity. It would be not easily doubted that debt accumulation is a serious economic problem, debt servicing is a desired task, while debt monetization is a way of postponing a financial breakdown and fighting deflation by a double-edged sword. This happens as debt monetization is beneficial against the "reflux theory" (Kaldor and Trevithick, 1981) of fast money destroying by repaying outstanding loans applying, but also increases uncertainty about viability of the "hot potato effect" of spending continuation.

\section{Arguments against debt monetization and money drops}

Inspected from a different angle, it is highly likely that debt monetization as a drastic discretionary action would lead to a significant loss of credibility regarding the monetary authorities. Apparently, this would render the financial system even more fragile in adverse shocks due to becoming increasingly addicted to 
and in need of unconventional action-taking. Issuing domestic fiat money to cover budget deficits and to confront deflationary pressures would be in danger of becoming normality, thereby constantly demanding for even more drastic measures because of marginally suffocating utility of new money-injecting rounds. Interbank market would either render more strictly regulated in order to counterbalance the high volatility of the ECB's decisions, or would go in tandem with ample liquidity provisions, pumping even more the already enlarged inflationary bubbles. Helicopter money drops would at least temporarily bring efficiency in trades and the overall economic system by also helping in monetizing debts. Nevertheless, the most important matter would be whether this far-fetched moneythriving inspiration could be perpetuated and if it could, for how long. Would inflationary pressures and the moral hazard effects due to free money available for risky-of-leading-to-zero-outcomes investments always remain counterbalanced by temporary financial sanity due to helicopter-arriving paramedics?

Cukierman (1994) supports that inflationary bias provoked by fuelling the economy with high-powered money persists long after the desirable impact of expansionary monetary policy has gone away. Despite inflation increasing employment due to the money illusion (Fisher, 2014) that brings lower labour costs to employers, this sequential game could not last for long before a response by the side of employees that would eventually lead to the same unemployment but higher CPI equilibrium. As Cukierman (1994) argues, inflation is negatively related to central bank independence, implying namely discretionary policy acting could not go towards a combination other than government interfering in monetary affairs. Buiter (2005) supports that non-independent monetary authorities exist and, specifically, that central bank plays a secondary role in relation to the government. He also argues that non-performing debt could be combined with fiscal policies in order to rationalize the initial stock of nominal government debt in accordance with rational expectations. Paralleling this state of affairs is conducive to the increasingly large significance of the government sector as a principal using an unwilling agent -the independent central bank- to pursue its objectives. Therefore, the responsibility is at least implicitly located in fiscal authorities, thereby enhancing opacity dynamics inside monetary committees. In line with the literature about central bank transparency and the closely related issue of monetary independence, there is mounting evidence that opacity due to lack of political transparency inducing to lower central bank independence (Geraats, 2002) took a quantum upward leap in cases of monetary expansions.

Interestingly, the Eurozone forms a special case within the broader context of the principal-agent problem, as it is made up of different national treasuries. Consequently, contentious issues about member debt-sharing could easily be brought 
about, providing an additional reason why the ECB independence should not be underemphasized. Although lending from the ECB and the ECSB is not allowed for national fiscal authorities, the same effect could be invoked by the government borrowing in a market and monetary authorities purchasing the same amount of fiscal debt in a secondary market. Disagreements among members of the EZ about having to share the fiscal burden of the weaker of them by unconventionally monetizing their debts, has helped cement a consensus that helicopter discretionary policy include a probability of leading to socially harmful inflation. Despite unconventional policy models providing evidence of a possible boost to the EZ economy due to LSAPs or overt money financing, no academic credence could be given for the claim that this could not turn to a negative outcome. Communication and cooperation noise among EZ members, as well as the differences in the intertemporal budget constraints of their governments, lead to the necessity of a stable banking and fiscal union in order to pertain the union sustainability and thereby their common targeting. In an effort to model helicopter money transfers to the private sector after having monetized national debts, a fortified government unanimity-led arsenal of EZ risk-sharing instruments should come to the forefront. Moreover, the ECB's reaction functions should for an indefinite time period stop being casted in terms of Taylor rules. Interestingly, debt monetizing could be given enough latitude to be maintained as a strong policy focus in the future as is much preferable than deflation evoking. As Blinder (1999) supports, monetary authorities are subject to much more pressure during contractionary policy phases, rather than during expansionary ones. Therefore, debt monetization permitting helicopter money dropping could enjoy a fair amount of consent. Nevertheless, it being far from a guardian of stability in the longrun, leads to diametrically opposed conclusions about its real effects to come. A large fraction of the debt monetization efficacy dynamics could be attributed to a trade-off between national accountability and monetary independence. Another, and a relevant one, fraction of this efficacy could intriguingly be based on the conceptualization of political transparency as openness about policy objectives in the form of modern money theory-based policymaking, which gives room for delicate helicopter piloting. Supportive evidence on a first round of unconventional debt monetization would be helpful in deciding about the cogency of such a policy perpetuation.

\section{Conclusions}

This paper is an attempt to discuss whether debt monetization in the Eurozone in the form of continuously renewed debtor-debtor interactions that perpetuate optimistic expectations could be viable. Modern money theory suggests that debt 
renewal could be carried on forever in order to ensure liquidity, thereby economic growth. This could happen via lowering the pessimism-evoking uncertainty embedded in interest rates.

A serious matter discussed is whether the loss of central bank credibility that ample helicopter money provisions could provoke could be counterbalanced by the accompanying inflationary growth-nourishing bulge. Irredeemability of debt is expected to bring better outcomes than QE measures have, but could also be less influential due to the higher moral hazard incentives and the diminishing marginal efficiency due to former unconventional rounds having taken place.

Bearing in mind the special "multiple principal-one agent" character of the relation between the EZ members and the ECB, the taking over by governments of the leader place in their nexus with the ECB should take place in order for helicopter money dropping to be efficient. This would highly likely mutate the opacity-fighting role of the ECB and render future credible commitment more difficult. A lack of past experience about debt monetizing in tandem with exceptionally unconventional monetary acting forms an impediment to expressing firm opinions about policy endurance. Despite difficulties, it is hoped that this work has succeeded in making even the slightest contribution towards the understanding of challenges that European monetary and fiscal authorities nowadays face in regard to debt monetization and overt money financing. 


\section{References}

1. Blinder, A. S. (1999). Central Banking in Theory and Practice. MIT Press.

2. Buiter, W. H. (2005). New developments in monetary economics: two ghosts, two eccentricities, a fallacy, a mirage and a mythos. The Economic Journal, 115(502), C1-C31.

3. Buiter, W. H., \& Sibert, A. C. (2007). Deflationary bubbles. Macroeconomic Dynamics, 11(04), 431-454.

4. Cukierman, A. (1994). Central bank independence and monetary control. The Economic Journal, 104(427), 1437-1448.

5. Fisher, I. (2014). The money illusion. Start Publishing LLC.

6. Geraats, P. (2002). Central Bank Transparency. Economic Journal, 112(483), 532-565.

7. Kaldor, N., \& Trevithick, J. (1981). A Keynesian perspective on money. Lloyds Bank Review, 139(1), 1-19.

8. Kim, J. (2011). How modern banking originated: The London goldsmithbankers' institutionalisation of trust. Business History, 53(6), 939-959.

9. McLeay, M., Radia, A., \& Thomas, R. (2014). Money creation in the modern economy. Bank of England Quarterly Bulletin, Q1.

10. Mehrling, P. (2000). Modern money: fiat or credit? Journal of Post Keynesian Economics, 22(3), 397-406.

11. Minsky, H. P., \& Kaufman, H. (2008). Stabilizing an unstable economy (Vol. 1). New York: McGraw-Hill.

12. Sgambati, S. (2016). Rethinking banking. Debt discounting and the making of modern money as liquidity. New Political Economy, 21(3), 274-290.

13. Shiller, R. J. (2015). Irrational exuberance. Princeton University Press. 